\title{
Observasi Gaya Kepemimpinan Terhadap Kinerja Pekerja Pada Proyek Preservasi Rekonstruksi Jalan Surabaya-Gresik-Sadang
}

\author{
${ }^{1}$ Totok Dwi Sutanto, ${ }^{2}$ Sugeng Dwi Hartantyo \\ 1,2 Program Studi Teknik Sipil, Fakultas Teknik, Universitas Islam Lamongan \\ email: totokdwi553@gmail.com
}

\begin{abstract}
Abstrak
Gaya kepemimpinan dalam perusahaan atau dalam lokasi proyek adalah merupakan suatu hal yang sangat mempengaruhi berlangsungnya pekerjaan. Akibat yang bisa timbul dari penerapan gaya kepemimpinan yang tidak tepat dapat mempengaruhi jalanya suatu pekerjaan dan otomatis memberikan dampak yang sangat buruk terhadap keberhasilan atau kelancaran proyek. Penelitian ini bertujuan untuk mengetahui pengaruh gaya kepemimpinan dengan menerapkan indikator gaya kepemimpinan sifat, tempramen, kebiasaan, watak serta kepribadian. Metode analisa yang digunakan dalam penelitian ini adalah uji validitas, uji reabilitas, uji determinasi $(R)$ dan uji t. Data diperoleh dari menyebarkan angket berupa kuesioner yang disebarkan dilokasi penelitian. Hasil yang dicapai dalam penelitian menunjukan hasil uji validitas dan uji reabilitas menunjukan valid dan realibel, tingkat kesalahan $95 \%$ atau 0,05 menghasilkan hasil uji determinasi menghasilkan $88 \%$ variasi variabel kinerja pekerja dapat dijelaskan oleh variabel gaya kepemimpinan.sementara uji t menghasilkan hasil $X 1=2,71$, $X 2=3,230, X 3=4,278, X 4=7,217$ dan $X 5=3,253$ dan semuanya signifikan, dari hasil pengujian dapat diartikan bahwasanya gaya kepemimpinan memiliki pengaruh yang signifikan dan positif terhadap kinerja.
\end{abstract}

Kata kunci: Gaya Kepemimpinan, Pengaruh, Kinerja Pekerja.

\begin{abstract}
Leadership style within the company or in the project location greatly influences the work progress. The use of improper leadership style would influence the execution of the project, which would have a negative impact on the success of the project. This study aims to determine the influence of leadership style by using several indicators of leadership style, namely traits, temperament, habits, character and personality. The analytical method used in this study is the validity test, reliability test, determination test $(R)$ and t-test. The data was obtained using questionnaires distributed at the research location. The results of the study indicated that the validity test and the reliability test was shown to be valid and reliable, an error rate of $95 \%$ or 0.05 resulted in the determination test results, which produced $88 \%$ of the variable variation in employee performance which can be explained by leadership style variables. While the t-test yielded the results of $X 1=2,71, X 2=3,230, X 3=4,278, X 4=7,217$ and $X 5=3,253$, all of which are significant. Based on the results of the test, it can be interpreted that the leadership style has a significant and positive influence on performance.
\end{abstract}

Keywords: Leadership style, influence, workers' performance

Diterima : Juni 2020

Disetujui: Juni 2020

Dipublikasi: Juni 2020
(C2020 Totok Dwi Sutanto, Sugeng Dwi Hartantyo Under the license CC BY-SA 4.0

\section{Pendahuluan}

Bertambahnya penduduk atau pemekaran manusia memiliki dampak terhadap situasi perkembangan infrastruktur yang ada, tidak lain juga termasuk terhadap proyek pembangunan jalan-jalan yang saat ini digenjot untuk menyepadankan terhadap pertumbuhan penduduk yang diimbangi infrastuktur yang baik (Ferdiansyah, 2018). 
Untuk itu gaya kepemimpinan dalam proyek merupakan hal yang sangat mutlak dalam sebuah organisasi proyek pada zaman modern saat ini dalam melaksanakan tugas atau kerja dan kepemimpinan untuk organisasi proyek karena gaya kepemimpinan bisa mempengaruhi langsung terhadap pekerja (Wiranata, 2011). Gaya kepemimpinan dapat didefinisikan sebagai sifat, kebiasaan, tempramen, watak dan kepribadian yang membedakan seorang pemimpin dalam berinteraksi dengan orang lain (Kartono,2008).

Menurut Miftah Toha (1993) bahwa gaya kepemimpinan adalah perilaku yang digunakan oleh seseorang pada saat orang tersebut mencoba mempengaruhi orang lain. Akibat dari gaya kepemimpinan yang buruk bisa menurunkan kinerja dari pekerja yang berdampak langsung terhadap kelangsungan proyek dan juga keberhasilan proyek dalam mencapai waktu begitu pula yang disampaikan. Oleh karena itu penelitian ini bertujuan untuk mengetahui adanya pengaruh gaya kepemimpinan secara parsial dari indikator yang disampaikan (Kartono, 2008) terhadap kinerja pekerja yang ada dilokasi proyek preservasi rekonstruksi jalan Surabaya-GresikSadang.

\section{Metode}

Lokasi penelitian terletak di proyek preservasi rekonstruksi jalan SurabayaGresik-Sadang. Penelitian ini menggunakan metode survey lapangan, menyusun kisikisi instrument penelitian, validitas instrument, menyebarkan angket atau kuesioner, penarikan angket, mengolah data, penentuan keterkaitan pengaruh dan membuat rangkuman pembahasan.

Dalam menyebarkan angket tentunya ditentukan populasi dan sampel penelitian dimana pada penelitian kali ini menggunakan 63 orang kemudian dihitung menggunakan rumus slovin yang pada akhirnya menemukan sampel dari penelitian ini adalah 39 orang.

$$
n=\frac{N}{1+N(e)^{2}}
$$

Keterangan :

$\mathrm{n}=$ Ukuran sampel/jumlah responden

$\mathrm{N}=$ Ukuran populasi

$\mathrm{e}=$ Presentase kelonggaran ketelitian kesalahan pengambilan sampel yang masih bisa ditolerir

Setelah menyebarkan angket terlebih dahulu dilakukan analisa deskriptif terhadap responden yang meliputi umur, tingkat pendidikan dan jenis kelamin. Untuk memudahkan dalam melakukan pengolahan data secara matematis maka dilakukan pemberian kode pada setiap jawaban responden. Pemberian kode menggunakan 
(skala Likert), setelah semua data terkumpul kemudian dilakukan pengolahan data, dalam pengolahan data menggunakan alat bantu program SPSS dimana dengan analisa data menggunakan Uji validitas menggunakan tingkat kepercayaan 95\%, dan dasar pengambilan keputusan:

- Jika rhasil positif, serta rhasil > rtabel, maka butir pertanyaan tersebut valid

- Jika rhasil negatif, serta rhasil < rtabel, maka butir pertanyaan tersebut tidak valid. dan realibilitas data dengan dasar pengambilan keputusan:

- Jika Cronbach Alpha > rtabel, maka dapat dikatakan reliabel.

- Jika Cronbach Alpha < rtabel, maka dapat dikatakan tidak reliabel.

yang kemudian diteruskan kedalam analisa uji $r$ untuk mengukur seberapa jauh kemampuan variabel-variabel bebas dalam menerangkan variabel terikatnya dan uji untuk mengetahui pengaruh dengan melihat nilai $t$ hitung dan taraf signifikansi, jika taraf signifikansi yang dihasilkan dari perhitungan dibawah 0,05 maka Ha diterima, sebaliknya jika taraf signifikansi hasil hitung lebih besar dari 0,05 maka Ho diterima.

\section{Hasil dan Pembahasan}

Hasil

Hasil uji validitas menunjukkan pada semua indikator yang digunakan untuk mengukur variabel-variabel yang digunakan dalam penelitian ini mempunyai koefisien korelasi lebih besar dari $r$ tabel. $(0,31) d f=n-2=(39-2)=37$, pada tarif signifikansi 0,05 . Artinya semua indikator sebagai pengukur dari masing-masing varibel tersebut adalah valid.

Tabel 1 hasil Uji Validitas

\begin{tabular}{c|cccc}
\hline \multirow{2}{*}{ Variabel } & No & $\begin{array}{c}\mathrm{R} \\
\text { Hitung }\end{array}$ & $\begin{array}{c}\mathrm{R} \\
\text { Tabel }\end{array}$ & Keterangan \\
\hline \multirow{3}{*}{ Sifat (X1) } & X1.1 & 0,698 & 0,31 & Valid \\
& X1.2 & 0,807 & 0,31 & Valid \\
& X1.3 & 0,791 & 0,31 & Valid \\
& X1.4 & 0,713 & 0,31 & Valid \\
\hline \multirow{3}{*}{ Tempramen } & X2.1 & 0,784 & 0,31 & Valid \\
(X2) & X2.2 & 0,893 & 0,31 & Valid \\
& X2.3 & 0,831 & 0,31 & Valid \\
& X2.4 & 0,843 & 0,31 & Valid \\
\hline \multirow{4}{*}{ Kebiasaan } & X3.1 & 0,843 & 0,31 & Valid \\
(X3) & X3.2 & 0,791 & 0,31 & Valid \\
& X3.3 & 0,788 & 0,31 & Valid \\
& X3.4 & 0,839 & 0,31 & Valid \\
\hline \multirow{2}{*}{ Watak (X4) } & X4.1 & 0,856 & 0,31 & Valid \\
& X4.2 & 0,578 & 0,31 & Valid
\end{tabular}




\begin{tabular}{|c|c|c|c|c|}
\hline & $\begin{array}{r}X 4.3 \\
\times 4.4 \\
\end{array}$ & $\begin{array}{l}0,676 \\
0,806\end{array}$ & $\begin{array}{l}0,31 \\
0,31 \\
\end{array}$ & $\begin{array}{l}\text { Valid } \\
\text { Valid } \\
\end{array}$ \\
\hline \multirow{4}{*}{$\begin{array}{l}\text { Kepribadian } \\
\text { (X5) }\end{array}$} & $X 5.1$ & 0,657 & 0,31 & Valid \\
\hline & $\times 5.2$ & 0,847 & 0,31 & Valid \\
\hline & X5.3 & 0,621 & 0,31 & Valid \\
\hline & $\times 5.4$ & 0,560 & 0,31 & Valid \\
\hline
\end{tabular}

Hasil uji reliabilitas menunjukkan nilai Cronbach's Alpha pada semua variabel bebas (Sifat, Tempramen, Kebiasaan, Watak dan Kepribadian) dan variabel terikat lebih besar dari standart reliabilitas $(0,60)$ dengan tingkat signifikan $a=5 \%$, sehingga dapat disimpulkan bahwa instrument dalam variabel bebas dan terikat adalah reliable seperti hasil pengolahan pada tabel 2 .

Tabel 2 hasil Uji Reliabilitas

\begin{tabular}{ccccc}
\hline No & Variabel & $\begin{array}{c}\text { Koefisien } \\
\text { Alpha }\end{array}$ & $\begin{array}{c}\text { Standar } \\
\text { Reliabilitas }\end{array}$ & Keterangan \\
\hline 1 & Sifat $(\mathrm{X} 1)$ & 0,745 & 0,60 & Reliabel \\
\hline 2 & Tempramen $(\mathrm{X} 2)$ & 0,858 & 0,60 & Reliabel \\
\hline 3 & Kebiasaan $(\mathrm{X} 3)$ & 0,829 & 0,60 & Reliabel \\
\hline 4 & Watak $(\mathrm{X} 4)$ & 0,719 & 0,60 & Reliabel \\
\hline 5 & Kepribadian $(\mathrm{X} 5)$ & 0,607 & 0,60 & Reliabel \\
\hline
\end{tabular}

Dari sejumlah data kuesioner yang telah disebarkan sebanyak 39, diambil dan diolah, maka terdapat data-data responden dari pekerja Proyek Preservasi Rekonstruksi Jalan Surabaya-Gresik-Sadang. Data-data tersebut dapat dirangkum dan disajikan dalam tabel 3.

Tabel 3 hasil Jenis Kelamin Responden Jenis Kelamin

\begin{tabular}{|c|c|c|c|c|c|}
\hline & & Frequency & Percent & $\begin{array}{c}\text { Valid } \\
\text { Percent }\end{array}$ & $\begin{array}{c}\text { Cumulative } \\
\text { Percent }\end{array}$ \\
\hline valid & Laki- & 39 & 100 & 100 & 100 \\
\hline
\end{tabular}

\section{Deskripsi Umur Responden}

Dari sejumlah data kuesioner yang telah disebarkan sebanyak 39, diambil dan diolah, maka terdapat data-data responden dari pekerja Proyek Preservasi Rekonstruksi Jalan Surabaya - Gresik - Sadang. Data-data tersebut dapat dirangkum dan disajikan dalam tabel 4. 
Tabel 4 Hasil Umur Responden

Umur

\begin{tabular}{llrrrr}
\hline & Frequency & Percent & $\begin{array}{c}\text { Valid } \\
\text { Percent }\end{array}$ & $\begin{array}{c}\text { Cumulative } \\
\text { Percent }\end{array}$ \\
\hline \multirow{4}{*}{ valid } & 20 - 29 Tahun & 15 & 38.5 & 38.5 & 38.5 \\
& 30 - 39 Tahun & 16 & 41 & 41 & 79.5 \\
& 40 -50 Tahun & 8 & 20.5 & 20.5 & 100 \\
& Total & 39 & 100 & 100 & \\
\hline
\end{tabular}

Sumber : Hasil Pengolahan SPSS

\section{Deskripsi Tingkat Pendidikan Responden}

Dari sejumlah data kuesioner yang telah disebarkan sebanyak 39, diambil dan diolah, maka terdapat data-data responden dari pekerja Proyek Preservasi Rekonstruksi Jalan Surabaya - Gresik - Sadang. Data-data tersebut dapat dirangkum dan disajikan dalam tabel 5.

Tabel 5 Hasil Tingkat Pendidikan Responden

\begin{tabular}{|c|c|c|c|c|c|}
\hline \multicolumn{6}{|c|}{ Pendidikan } \\
\hline & & Frequency & Percent & $\begin{array}{c}\text { Valid } \\
\text { Percent }\end{array}$ & $\begin{array}{c}\text { Cumulative } \\
\text { Percent }\end{array}$ \\
\hline \multirow{4}{*}{ Valid } & SD & 16 & 41 & 41 & 41 \\
\hline & SMP & 19 & 48.7 & 48.7 & 89.7 \\
\hline & SMA & 4 & 10.3 & 10.3 & 100 \\
\hline & Total & 39 & 100 & 100 & \\
\hline
\end{tabular}

\section{Uji R Determinasi}

Dari hasil perhitungan uji $\mathrm{R}$ dapat diketahui bahwa koefisien determinasi (adjusted R) yang diperoleh sebesar 0,880. Hal ini berarti 0,880 dikalikan 100 sama dengan $88 \%$ variasi variabel kinerja pekerja dapat dijelaskan oleh variabel gaya kepemimpinan seperti yang ditampilkan tabel 6 .

Tabel 6 Hasil Uji R

\section{Model Summary}

\begin{tabular}{lllll}
\hline Model & $\mathrm{R}$ & R Square & $\begin{array}{l}\text { Adjusted R } \\
\text { Square }\end{array}$ & $\begin{array}{l}\text { Std. Error of } \\
\text { the Estimate }\end{array}$ \\
\hline 1 & $.946^{\mathrm{a}}$ & 0.896 & 0.88 & 0.577 \\
\hline \multicolumn{4}{c}{ Sumber : Hasil Pengolahan SPSS }
\end{tabular}




\section{Uji t}

Dari hasil uji t untuk variabel gaya kepemimpinan yang meliputi $\mathrm{X} 1$ (Sifat) nilai $t$ hitung sebesar 2,754 dengan sgnifikan 0,009, X2 (Tempramen) nilai t hitung sebesar 3,320 dengan nilai signifikan 0,003, X3 (Kebiasaan) nilai t hitung sebesar 4,278 dengan nilai signifikan $0,000, \mathrm{X} 4$ (Watak) nilai t hitung sebesar 7,217 dengan nilai signifikan 0,000, X5 (Kepribadian) nilai t hitung sebesar 3,253 dengan nilai signifikan 0,003 yang artinya dari beberapa variabel di atas kurang dari 0,05 , maka Ho ditolak dan $\mathrm{Ha}$ diterima. Hal ini berarti variabel gaya kepemimpinan berpengaruh signifikan terhadap kinerja pekerja.

\section{Coefficients $^{a}$}

\begin{tabular}{|c|c|c|c|c|c|c|}
\hline \multirow[b]{2}{*}{ Model } & & \multicolumn{2}{|c|}{$\begin{array}{l}\text { Unstandardized } \\
\text { Coefficients }\end{array}$} & \multicolumn{3}{|c|}{$\begin{array}{l}\text { Standardized } \\
\text { Coefficients }\end{array}$} \\
\hline & & $B$ & Std. Error & Beta & $\mathrm{t}$ & Sig. \\
\hline 1 & (Constant) & .500 & 1.738 & & .287 & .776 \\
\hline & total_x1 & .150 & .054 & .161 & 2.754 & .009 \\
\hline & total_x2 & .127 & .039 & .217 & 3.230 & .003 \\
\hline & total_x3 & .242 & .057 & .355 & 4.278 & .000 \\
\hline & total_x4 & .541 & .075 & .625 & 7.217 & .000 \\
\hline & total $\times 5$ & .185 & .057 & .188 & 3.253 & .003 \\
\hline
\end{tabular}

Sumber : Hasil Pengolahan SPSS

\section{Pembahasan}

Pembahasan Hasil penelitian pada observasi gaya kepemimpinan terhadap kinerja pekerja pada proyek preservasi rekonstruksi jalan Surabaya - Gresik - Sadang didapatkan bahwa gaya kepemimpinan yang meliputi indikator sifat, tempramen, kebiasaan, watak dan kepribadian berpengaruh terhadap kinerja, dapat dilihat dari hasil uji t pada X1 (sifat) diperoleh t hitung $(2,754)$, X2 (tempramen) diperoleh t hitung $(3,230)$, X3 (kebiasaan) diperoleh t hitung $(4,278), X 4$ (watak) diperoleh t hitung $(7,217)$ dan X5 (kepribadian) diperoleh t hitung $(3,253)$ dengan taraf signifikan 0,05 sehinggah $\mathrm{t}$ hitung $>\mathrm{t}$ tabel maka $\mathrm{H} 1$ diterima yang berarti ada pengaruh yang signifikan antara gaya kepemimpinan terhadap kinerja pekerja yang ada dilokasi proyek, dan juga nilai uji $r$ determinan diperoleh sebesar 0,880 yang artinya variasi variabel kinerja pekerja dapat dijelaskan oleh variabel gaya kepemimpinan.

\section{Kesimpulan}

Hubungan Gaya Kepemimpinan Terhadap Kinerja Pekerja Pada Proyek Preservasi Rekonstruksi Jalan Surabaya - Gresik - Sadang dengan hasil pengolahan data dari penelitian Uji Validitas dan Realibilitas menunjukan bahwa seluruh pernyataan dalam setiap variabel realibel dan valid. nilai Uji $R$ adalah 0,880 yang 
artinya $88 \%$ variasi variabel kinerja pekerja dapat dijelaskan oleh variabel gaya kepemimpinan dan uji t dari indikator Gaya Kepemimpinan X1 (sifat): 2,754, X2 (temperamen): 3,230, X3 (kebiasaan): 4,278, X4 (Watak): 7,217 dan X5: 3,523 yang artinya $>$ dari t tabel yang artinya dari indikator-indikator gaya kepemimpinan memiliki pengaruh secara parsial terhadap kinerja pekerja dan memiliki berpengaruh positif.

\section{Daftar Pustaka}

Ferdiansyah, M. (2018). Analisis pengaruh gaya kepemimpinan transformasional, kopensasi dan program pelatihan terhadap employee enggagement serta dampaknya terhadap kinerja karyawan di PT Angkasa Pura II (Persero). Jurnal Dinamika Manajemen dan Bisnis, 1(2), doi: https://doi.org/10.21009/JDMB.01.2.09.

Wiranata, A.A. (2011). Pengaruh kepemimpinan terhadap kinerja dan stres karyawan. Jurnal IImiah Teknik Sipil, 15(2), 155-160.

Kartono, K. (2008). Pemimpin dan kepemimpinan. Jakarta: PT. Raja Grafindo Persada.

Thoha, M. (1993). Dimensi-dimensi prima ilmu administrasi negara. Jakarta: Raja Grafindo Persada. 